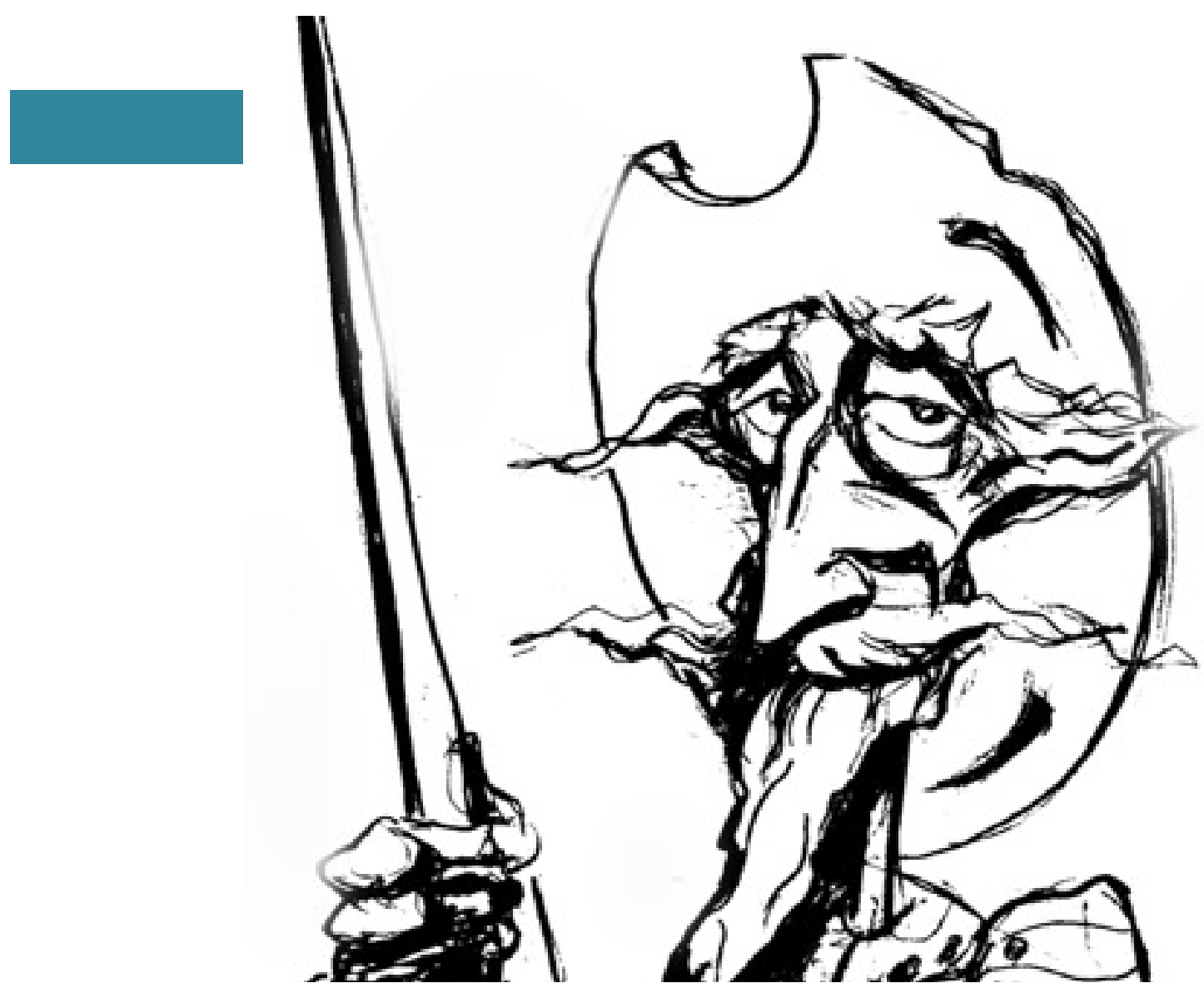

Enseñanza religiosa y educación laica en las escuelas públicas de Argentina (1884 a 2015)

[Laura Graciela Rodríguez] 


\title{
Enseñanza religiosa y educación laica en las escuelas públicas de Argentina (1884 a 2015)*
}

\author{
Religious Instruction and Secular Education in Public Schools in Argentina \\ (1884 - 2015)
}

LAURA GRACIELA RODRÍGUEZ

\section{Resumen}

En este artículo analizamos uno de los múltiples aspectos de la religiosidad o la laicidad, como son la dimensión jurídica y la inclusión de la enseñanza religiosa o la educación laica en las Constituciones Provinciales, Leyes y Decretos nacionales y provinciales de educación. En este trabajo buscamos efectuar un estudio de largo plazo que permita identificar los cambios y continuidades en relación a la enseñanza religiosa o la educación laica en las escuelas públicas estatales de nivel primario, tanto a nivel nacional como dentro de una misma provincia, desde 1884 hasta 2015.

\section{Palabras clave}

Laicismo - religión - educación - escuela

\begin{abstract}
In this article we analyze one of the many aspects of religiosity or secularism, such as the legal dimension and the inclusion of religious teaching or secular education in the provincial constitutions, laws and national and provincial decrees of education. In this work we seek to carry out a long-term study to identify changes and continuities in relation to religious education or secular education in state public primary schools, both nationally and within the same province, from 1884 to 2015.
\end{abstract}

Key words Laicism - religion - education - schools

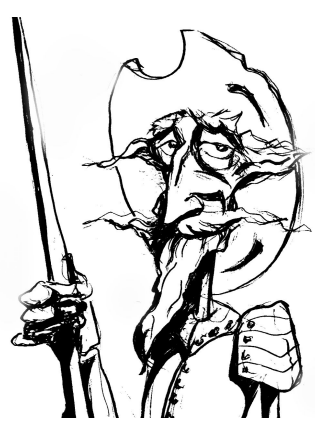

Recibido con pedido de publicación el 8 de abril de 2018

Aceptado para su publicación el 7 de julio de 2018

Versión definitiva recibida el 20 de septiembre de 2018

Laura Graciela Rodríguez, Consejo Nacional de Investigaciones Científicas y Técnicas, Universidad Nacional de La Plata, Argentina; e-mail: lau.g.rodrig@gmail.com

* Agradezco los comentarios de Germán Soprano y Mara Petitti, así como las sugerencias de los evaluadores anónimos de la Revista.

Esta obra se publica bajo licencia Creative Commons. Atribución-NoComercial-CompartirIgual (cc) EY-NC-sa 4.0 Internacional

Rodríguez, Laura Graciela “Enseñanza religiosa y educación laica en las escuelas públicas de Argentina (1884 a 2015)”, Prohistoria, Año XXI, núm. 30, dic. 2018, pp. 183-207. 
En este artículo partimos de la pregunta acerca de religiosidad o la laicidad del sistema educativo argentino. ${ }^{1}$ En Argentina se ha dado una situación singular: en la Constitución Nacional de 1853 (y luego la de 1994) nunca se hizo la separación formal entre Iglesia y Estado y ambas contemplaron la libertad de cultos, aunque no la igualdad religiosa, otorgando a la Iglesia Católica un lugar privilegiado frente a otras. ${ }^{2}$ En los párrafos que siguen se hará foco en uno de los múltiples aspectos de la religiosidad o la laicidad, como es la dimensión jurídica y la inclusión de la enseñanza religiosa o la educación laica en las Constituciones Provinciales, Leyes y Decretos nacionales y provinciales de educación. ${ }^{3}$ Diferentes investigadores han analizado varios aspectos de este conjunto de normas, incluido el que nos ocupa aquí. ${ }^{4}$ En general, han ofrecido un valioso estado de situación durante un período acotado. En este trabajo buscamos efectuar un análisis de más largo plazo, que permita identificar los cambios y continuidades en relación a la enseñanza religiosa o la educación laica en las escuelas públicas estatales de nivel primario, tanto a nivel nacional como dentro de una misma provincia, desde 1884 hasta 2015. En referencia a la "enseñanza religiosa", veremos que una amplia mayoría de sacerdotes católicos, funcionarios, docentes y padres ha entendido en distintas épocas que esta era sinónimo de "catequesis católica". Ciertamente, hubo funcionarios que evitaron utilizar esa expresión e incluyeron directamente la "enseñanza de la Religión Católica" en la normativa.

\footnotetext{
${ }_{1}^{1}$ Para no sobrecargar la escritura, en este texto se utilizará el género masculino clásico, en el entendido que incluye siempre a mujeres y hombres.

${ }^{2} \mathrm{Al}$ igual que en otras épocas, en 2018 se volvieron a presentar varios proyectos para separar el Estado de la Iglesia y eliminar el financiamiento estatal que recibe esta última.

${ }^{3}$ Se entiende por laicidad el proceso de sustracción a la autoridad religiosa de instituciones y de funciones que van pasando a la órbita del Estado, y que constituye un aspecto de un proceso mayor y más complejo, que es el de la secularización. La secularización, a su vez, es el proceso de pérdida de la capacidad normativa de la religión y el ajuste de los fenómenos que se producen en planos que empiezan a diferenciarse de ella: la política, la economía, la sociedad, la cultura, la ciencia. Decir que una sociedad se ha secularizado "implica que sus comportamientos han ganado autonomía respecto de la autoridad religiosa". DI STEFANO, Roberto "Por una historia de la secularización y de la laicidad en la Argentina", Quinto Sol, vol. 15, núm. 1, 2011, pp. 1-32.

${ }^{4}$ FURLONG, Guillermo La tradición religiosa en la escuela argentina, Theoria, Buenos Aires, 1957; BRAVO, Héctor Félix Bases constitucionales de la educación argentina. Un proyecto de reforma, CEAL, Buenos Aires, 1988; MALTONI, Marta Borthwick de Legislación educativa argentina comentada y comparada, Braga, Buenos Aires, 1995; MAGI, Margarita Elizabeth Enseñanza religiosa en la escuela estatal ¿Opción libre o imposición? Un desafío para la democracia argentina, Tesis de Doctorado en Ciencias de la Educación, Universidad Católica de Córdoba, 1997; RIVAS, Axeldirector- Las provincias educativas. Estudio comparado sobre el Estado, el poder y la educación en las 24 provincias argentinas, CIPPEC, Córdoba, 2003; ESQUIVEL, Juan Cruz "Religión y política en Argentina. La influencia religiosa en las Constituciones provinciales", en Actas del XXVII Congreso de la Asociación Latinoamericana de Sociología, ALAS Buenos Aires, 2009; TORRES, Germán "Tensiones por la laicidad educativa en la Argentina contemporánea", Congreso de la Asociación de Estudios Latinoamericanos, Nueva York, 2016.
} 
Ahora bien, a través de estas páginas desarrollaremos tres hipótesis vinculadas entre sí. En primer lugar, pretendemos mostrar que en términos de laicismo o religiosidad, ninguna de las tres leyes nacionales de educación se pronunció por la primera opción. Frente a la idea de sentido común que supone que la Ley 1420 de 1884 dispuso la educación laica, señalaremos que de las tres leyes nacionales, esta fue la única que incluyó enseñanza religiosa fuera del horario escolar (art. 8vo), mientras que en las otras dos (24195 de 1993 y 26206 de 2006) no se contempló la posibilidad de que se impartiese religión, ni dentro ni fuera del horario escolar. Más allá de los pronunciamientos públicos, podemos asegurar que las dos últimas leyes han configurado un avance relativo -la segunda más que la primera- con respecto a la neutralidad religiosa.

En segundo término, señalaremos que si bien existe una idea extendida que la Ley 1420 se implementó en todo el país, esta afirmación suele perder de vista las realidades de las provincias, que no estaban comprendidas por dicha norma. ${ }^{5}$ En este sentido, mostraremos que en las provincias más antiguas y en las nuevas, la situación fue heterogénea y cambiante a lo largo del tiempo, expresándose de manera diferente a las leyes nacionales. ${ }^{6}$ En distintas épocas las provincias se pronunciaron a favor: a) del laicismo; b) la enseñanza religiosa dentro del horario escolar; c) la enseñanza religiosa fuera del horario escolar; d) la neutralidad (ni enseñanza religiosa ni laicismo); e) o bien fueron oscilando entre el laicismo, la enseñanza religiosa y/o la neutralidad en distintos momentos históricos. Cabe aclarar que en este texto nos restringiremos a presentar la letra de la normativa, pero desconocemos la manera en que se implementaron las normas sancionadas a través de sus diseños curriculares. Esta cuestión es más difícil de reconstruir, aunque haremos alguna referencia cada vez que las fuentes lo permitan.

En tercer y último lugar, reseñaremos algunas notas periodísticas de los últimos años que evidencian cómo el catolicismo ha permeado las prácticas cotidianas de algunas escuelas, independientemente de la legislación sancionada. Observaremos que en la actualidad siguen coexistiendo distintas miradas sobre lo educativo, aun cuando podríamos asegurar que el consenso

\footnotetext{
${ }^{5}$ En 2014 la Comisión Bicameral del Digesto Jurídico Argentino propuso derogar la Ley 1420 por considerar que fue superada por otras normas. Legisladores, especialistas y parte de la prensa nacional expresaron que dicha derogación "podría abrir la puerta al regreso de la educación religiosa en las escuelas públicas", podría también "imponer la religión como materia", y que la medida era un "golpe de gracia al laicismo". Todas estas expresiones dan cuenta de la confusión respecto a la incumbencia y alcance de aquella Ley.

${ }^{6}$ Las provincias antiguas son las 14 (13 más la Capital Federal) que existían cuando se sancionó la Ley en 1884 y las nuevas son los 10 ex Territorios Nacionales que se provincializaron en las décadas de 1950 y 1990.
} 
mayoritario se encuentra del lado del rechazo a impartir religión católica en las escuelas públicas. ${ }^{7}$

\section{La nación y las provincias entre el siglo XIX y el XX}

La mencionada Constitución Nacional de 1853 le otorgó autonomía a las 14 provincias para que sancionaran sus propias Leyes de educación. La Ley de subvenciones de 1871 hizo que las provincias impulsaran nuevas normas y hacia 1884 la mayoría contemplaba la educación religiosa en el horario de clase, pero más de una tenía dificultades para impartir la materia. ${ }^{8}$ En diciembre de 1883, el Inspector Nacional de Escuelas Carlos N. Vergara realizó su informe sobre las escuelas en Mendoza. En el texto dirigido al presidente de la Comisión Nacional de Educación, Benjamín Zorrilla, informaba que la materia Religión era la "peor enseñada", aun cuando los maestros y niños eran todos católicos. Vergara decía que su enseñanza se limitaba a recitar de memoria el "Catecismo" de Benítez y esto causaba a los niños "adversión" y "hastío", "enfriándose de este modo en sus tiernos corazones, uno de los sentimientos más grandes y más benéficos que abriga el espíritu humano". ${ }^{9}$

En 1884, luego de largos debates entre liberales y católicos en el seno del Congreso Pedagógico de 1882, se aprobó la Ley de Educación 1420, que, como ya dijimos, no hacía ninguna mención a la laicidad y establecía la implementación de la enseñanza religiosa fuera del horario escolar (art. 8). Recordemos que la norma debía aplicarse en la Capital Federal y los Territorios Nacionales. Estos últimos representaban alrededor de la mitad de la superficie total, se caracterizaban por tener una importante población aborigen y una presencia creciente de las órdenes religiosas que se ocuparon de la educación y de la "conversión a los indígenas al catolicismo" de acuerdo al artículo 64 (inciso 15) de la Constitución Nacional (1853). ${ }^{10}$ De todos modos, hubo una

\footnotetext{
7 Un estudio estadístico de 2013 reveló que solo un 14,4 \% de la población argentina general considera que se debe impartir religión católica en las escuelas públicas (este porcentaje varía en cada provincia), aunque un 54,6\% cree que tiene que haber una materia general sobre religión y un 26,9\% que no debe haber enseñanza religiosa, ver MALLIMACI, Fortunato (dir.) Atlas de las creencias religiosas en la Argentina, Biblos, Buenos Aires, 2013, p. 213.

${ }^{8}$ Por citar alguna, la Ley de Educación común de Tucumán (492 de 1883) en su art. 6 establecía "la necesidad de formar el carácter de los hombres por la enseñanza de la religión (...) debiendo la comisión central al organizar la enseñanza religiosa, respetar las creencias de los padres de familia ajenos a la comunión católica".

9 El Monitor, Buenos Aires, núm. 491, 1884, p. 392. Para esos años también se dio religión en las primeras Escuelas Normales, como la de Paraná (creada en 1870 por Domingo F. Sarmiento) durante la dirección del español José M. Torres entre 1876 y 1885, y la Normal "Mariano Acosta" de Capital Federal bajo el rectorado de Adolfo Van Gelderen (1874-1881).

${ }^{10}$ Para conocer la obra de los franciscanos en el Nordeste del país y de los salesianos en el sur, ver DALLA- CORTE CABALLERO, Gabriela Mocovíes, franciscanos y colonos en la zona chaqueña de Santa Fe (1850-2011), Prohistoria, Rosario, 2012; NICOLETTI, María Andrea “La congregación
} 
inmediata reacción de parte de los representantes de la Iglesia Católica en las provincias, contra la sanción de la Ley 1420. A lo largo del año 1884 sacerdotes, obispos y/o "vecinos" en Córdoba, Salta, Santiago del Estero, Jujuy, Catamarca y La Rioja, criticaron, por un lado, el hecho de que las escuelas públicas tuviesen al frente maestros formados en el laicismo; y por el otro, a las Escuelas Normales que estaban bajo la dirección de maestras norteamericanas de religión protestante que había hecho traer Domingo F. Sarmiento. En sus cartas pastorales les pedían a los padres que retirasen a sus hijos, y en varios casos así lo hicieron. Los eclesiásticos debieron moderar sus discursos cuando el Poder Ejecutivo Nacional expulsó al nuncio apostólico a fines de 1884 y se rompieron las relaciones diplomáticas con la Santa Sede. ${ }^{11}$

Como hemos mencionado, la enseñanza religiosa contemplada en la Ley fue interpretada mayoritariamente como sinónimo de "educación católica" por las autoridades eclesiásticas y los miembros de la comunidad educativa. Una de las cuestiones más objetadas por referentes católicos era que la enseñanza religiosa fuera del horario escolar resultaba muy difícil de implementar, ya que las escuelas habían comenzado a funcionar con dos o tres turnos. El problema era que ni bien salían unos alumnos entraban otros, por lo tanto no había en los hechos, ningún "antes" o "después" disponible. ${ }^{12}$

Más allá de estos discursos, existe un consenso entre los analistas que los católicos solían compartir con los liberales los mismos círculos de sociabilidad y gran parte de la elite no cuestionaba el carácter cristiano de la "civilización" que debía implantarse. ${ }^{13}$ Ambos estuvieron de acuerdo en aprobar los programas de "Moral y Urbanidad" de 1888, que incluyeron los contenidos "Deberes para con

salesiana en la Patagonia: civilizar, educar y evangelizar a los indígenas (1880-1934)", Estudios interdisciplinarios de América Latina y el Caribe, vol. 15, 2004, pp. 71-92.

${ }^{11}$ CAMPOBASSI, José S. Laicismo y catolicismo en la educación pública argentina, Ediciones Gure, Buenos Aires, 1961. Una excepción fue el caso de la directora de la Escuela Normal de Jujuy, que estuvo a cargo de una de las pocas maestras norteamericanas católicas, Mary Jeannette (Juana) Stevens (1884-1903). Dicha directora había conseguido autorización para dar catequesis hasta que el inspector Leopoldo Lugones le ordenó retirar las imágenes religiosas, episodio que generó su definitivo alejamiento. Ver YÉPEZ, Daniel “Jujuy 1884: La confrontación Estado civil e Iglesia. La sanción de la Ley1420 y la rebelión antilaicista del obispo Rizo Patrón", Historia de la Educación. Anuario, vol. 16, núm. 1, pp. 39-62, 2015; BERTONI, Lilia Ana “¿Estado confesional o estado laico? La disputa entre librepensadores y católicos en el cambio del siglo XIX al XX", en: BERTONI, Lilia Ana y PRIVITELLIO, Luciano de (comps.) Conflictos en democracia. La vida política argentina entre dos siglos, Siglo XXI, Buenos Aires, 2009, pp. 45-70.

${ }^{12}$ FURLONG, Guillermo La tradición religiosa..., cit., p. 101. En 1918 los socialistas pidieron, sin conseguirlo, que se suprimiera el artículo 8 vo en virtud de que no satisfacía a ninguna de las dos partes, ni a católicos ni a laicistas. Cit. en FURLONG, Guillermo La tradición religiosa..., cit., p. 103.

${ }^{13}$ LIONETTI, Lucía "La educación pública: escenario de conflictos y acuerdos entre católicos y liberales en la Argentina de fines del siglo XIX y comienzos del XX", Anuario de Estudios Americanos, vol. 63, 2006, pp. 77-106. 
Dios" (Cuarto Grado), "Amor y respeto a Dios como Creador y Providencia" (Cuarto Grado), aclarando siempre que los maestros debían abstenerse a dictar dogmas y doctrinas religiosas particulares. Unos años después, en "Instrucción Moral" se contemplaba en "La moral en acción" la "sumisión a la autoridad de la ley y de reverencia a Dios y obediencia a sus leyes" (inc. f, Cuarto Grado) y "Deberes para con Dios" (inc. f, Quinto y Sexto Grado). ${ }^{14}$ Otras provincias también preveían cuestiones similares para "Moral". ${ }^{15}$ Asimismo, libros como Las Fiestas Patrias de 1907 (3ra. Edición) tenían lecturas que invocaban a Dios y otras directamente religiosas como "La oración de María". ${ }^{16}$ De todos modos, como bien observaba un funcionario, el dictado de este tipo de contenidos dependía mucho de los maestros que estuviesen al frente del aula (ver infra).

Después de 1884 en las provincias se fueron sancionando nuevas leyes de educación que terminaron conformando un heterogéneo y cambiante mapa en referencia a la enseñanza religiosa (ver Cuadro). Lo que puede observarse es una tendencia de las autoridades provinciales a ejercer su derecho de autonomía respecto de nación, es decir, en esta etapa ninguna jurisdicción dispuso la enseñanza religiosa fuera del horario escolar. Se estableció la enseñanza religiosa [en adelante ER] o la enseñanza de la Religión Católica dentro del horario de clase [en adelante HC] en Santa Fe (1886), Salta (Leyes 31 de 1886 y 164 de 1889) y Córdoba (Leyes 1426 de 1896 y 2023 de 1908). ${ }^{17}$ En esta última, en 1923 se sancionó la Constitución Provincial [en adelante CP] que consagró la ER en las escuelas públicas. ${ }^{18}$ En el caso de que los padres

\footnotetext{
${ }^{14}$ ZORRILLA, Benjamín y GARCÍA, Julio "Sesiones del Consejo Nacional de Educación. Planes de estudios, programas y horarios para las escuelas comunes", El Monitor de la Educación Común, Consejo Nacional de Educación, 1888, pp. 385-432; Consejo Nacional de Educación, Digesto de Instrucción Primaria. Leyes, decretos y resoluciones vigentes para escuelas dependencias del Consejo Nacional de Educación, Consejo Nacional de Educación, Buenos Aires, 1920.

${ }^{15}$ Por ejemplo, en Jujuy el Programa de 1895 de "Instrucción Cívica y Moral" contenía: "Deberes para con Dios" y "Prácticas religiosas" en Quinto Grado.

16 "La oración de María" comenzaba: "A ti Dios de mis padres, a ti. Dios de los buenos, único rey del mundo, Dios de la tierra y cielo". VALLESCOS, Román Las Fiestas Patrias. Tratado de la preparación y ejecución de los actos cívicos en las escuelas de la República, Talleres Gráficos Sola y Franco, Buenos Aires, 1907 (3ra. Edición), p. 122.

${ }_{17}$ Santa Fe (1886), art. 7: "Podrán los párrocos o sacerdotes que la Curia Eclesiástica designe explicar la religión en el local de la escuela, señalándose a este efecto una hora por semana y sin que puedan contrariarse las creencias de los padres de familia ajenos al catolicismo. Art 8: El mínimum de instrucción primaria en toda escuela pública o privada será: (...) Religión y Moral Católica"; Salta, Leyes 31 (1886) y 164 (1889), art. 2: "Es obligatoria la enseñanza de la Religión Católica en las escuelas elementales"; Córdoba, Ley 1426 de 1896 y Ley 2023 de 1908, art. 3: "Es de necesidad primordial la formación del carácter de los niños por la enseñanza de la moral y de la religión"; art. 9: El mínimum de instrucción primaria obligatoria en toda escuela (...) comprenderá: (...) 3. Religión. 4. Moral y Urbanidad."

18 ABRATTE, Juan Pablo “Las huellas de la ley 1.420 en la Provincia de Córdoba: Legislación educativa y enseñanza religiosa en perspectiva histórico-política", Anuario. Historia de la Educación, vol.16, núm.1, 2015, pp. 25-38; ROITENBURD, Silvia “Educación y control social. El
} 
profesaran otros credos o ninguno, todas estas normas contemplaban la enseñanza de "Moral" en su reemplazo. Teniendo esta posibilidad, solía suceder que los niños preferían recibir ER y así evitar ser apartados y/o estigmatizados dentro del grupo de clase. En un movimiento contrario, se dispuso que la educación fuera laica en las CP de Entre Ríos (1885 y 1933), Mendoza (1916) y Santiago del Estero (1924). En Santa Fe se dio una breve experiencia laicista entre 1934 y $1935 .{ }^{19}$ En la provincia de Buenos Aires se omitió la ER en 1905 por Ley 2934 (que estaba en la Ley 988 de 1875), aunque no se adhirió al laicismo.

En las provincias donde estaba previsto que se diese religión dentro del $\mathrm{HC}$, se presentaban conflictos de distinto tipo cada vez que se creaban en esas jurisdicciones alguna de las instituciones educativas nacionales como las Escuelas Normales, los Colegios Nacionales y las escuelas primarias o "Láinez" (a partir de 1905), que se regían por la Ley $1420 .{ }^{20}$ Lo cierto es que avanzado el siglo XX continuaban las críticas y opiniones diferentes sobre la Ley. Un importante referente de la Iglesia Católica no dudaba en afirmar que la Ley 1420 estaba "en contradicción con toda la tradición argentina, desde 1536 hasta 1884", y era "antiargentina, anticonstitucional, anticatólica, antipedagógica, antidemocrática, antifilosófica y antihumana". ${ }^{21}$ Al mismo tiempo, otro sector de la Iglesia remarcaba que la Ley 1420 no era "laica por sí misma, ya que el artículo 8vo contempla la posibilidad de la enseñanza religiosa en las escuelas públicas", resaltando que en su texto ni siquiera figuraba "el calificativo laico ni neutro". ${ }^{22}$ Por su parte, los socialistas afirmaban que la Ley 1420 había creado la "escuela popular, gratuita y laica". ${ }^{23}$

Sin desconocer que hubo docentes que defendieron el laicismo, testimonios en distintas épocas dan cuenta que una parte de los maestros argentinos era católica y esto teñía su práctica en el aula. La investigadora Adriana Puiggrós ha señalado que desde 1880 el catolicismo "se manifestó en la

nacionalismo Católico Cordobés (1862-1944)", en OSSANA, Edgardo (coord..) La educación en las provincias y territorios nacionales (1884-1945), Galerna, Buenos Aires, 1993, pp. 59-120.

${ }^{19}$ MAURO, Diego “Procesos de laicización en Santa Fe (Argentina): 1860-1900. Consideraciones sobre la Argentina liberal y laica", Revista de Indias, núm. 261, 2014, pp. 539-560; MAURO, Diego "Catolicismo, educación y política. La enseñanza religiosa entre la curia diocesana y las orientaciones educativas del estado provincial. Santa Fe, 1915-1937", Estudios Sociales, núm. 36, 2009, pp. 143- 172.

${ }^{20}$ Manuel Gálvez escribió en su novela La maestra normal de 1914, que tanto las Escuelas Normales como los Colegios Nacionales contribuían, por su falta de enseñanza religiosa, a expandir los malos hábitos en las provincias. Decía que el normalismo era perjudicial porque era "laico, anticlerical y dogmático" y que el Colegio Nacional era un "antro de inmoralidad". GALVEZ, Manuel La maestra normal, Losada, Buenos Aires, [1914], 1964.

${ }^{21}$ FURLONG, Guillermo La tradición religiosa..., cit., p. 90.

22 DEL COL, José Juan La dimensión religiosa en la educación pública estatal a la luz del Congreso Pedagógico Nacional. Estudio documental, Bahía Blanca, Ediciones CUSSA, 1990, p. 23.

${ }^{23}$ La Vanguardia, 10 diciembre 1969, p. 4. 
escuela pública en el propio discurso escolar, que incluyó elementos religiosos en los libros de texto, en los discursos de las conferencias pedagógicas, en disertaciones de los funcionarios y en la palabra cotidiana de muchos maestros". ${ }^{24}$ En los años de 1920 el escritor y ex inspector Leopoldo Lugones advertía que las directoras y maestras habían convertido a las escuelas "en centros de propaganda religiosa", donde imperaba "el dogmatismo" ${ }^{25}$

Desde las primeras décadas del siglo XX, la Iglesia Católica se dedicó a fortalecer su actividad religiosa y a ocuparse de manera especial por la cuestión social, en un intento de superar el liberalismo y contener el avance del comunismo. Contribuyó a la confesionalización del Ejército y entre ambos construyeron el mito de la "nación católica" que se cristalizó alrededor de $1930 .{ }^{26}$ A tono con el escenario más general, en 1931 fundó Acción Católica, en 1936 la Federación de Maestros y Profesores Católicos, y en 1939 el Episcopado creó el Consejo Superior de Educación Católica o CONSUDEC (el primer intento había sido en 1925). En ese contexto, en 1934 el presidente del Consejo Nacional de Educación, el ingeniero Octavio Pico, dijo que si bien la Ley 1420 le había asignado "un lugar exiguo al desarrollo del sentimiento religioso", innumerables "maestros y maestras han llenado por sí mismos este vacío y elevado el espíritu de sus educandos al conocimiento de esas verdades", mientras que otros, "más pusilánimes, más indiferentes o más sectarios, han omitido toda alusión a esas altas manifestaciones del espíritu humano y han llegado hasta suprimir en los libros de lectura la mención del nombre de Dios". $^{\prime 27}$

En 1936 provincias como Santa Fe, Catamarca (por decreto 403/36) y Buenos Aires, re instauraron la ER en las escuelas públicas. ${ }^{28}$ En suma, hacia 1943 se impartía religión en las provincias de Buenos Aires, Santa Fe, Catamarca, Córdoba (desde 1896) y Salta (desde 1886). ${ }^{29}$ En diciembre de 1943, los militares y civiles que encabezaron el golpe de Estado y su ministro del área,

24 PUIGGRÓs, Adriana Sujetos, disciplinas y curriculum en los orígenes del sistema educativo argentino (1885-1916)- Tomo 1 Historia de la educación argentina, Galerna, Buenos Aires, 1992, p. 41.

${ }^{25}$ Citado en FIORUCCI, Flavia "País afeminado, proletariado feminista. Mujeres inmorales e incapaces: la feminización del magisterio en disputa (1900-1920)", Anuario de Historia de la Educación, vol. 17, núm. 2, 2016, p. 126.

${ }^{26}$ ZANATTA, Loris Del estado liberal..., cit.

${ }^{27}$ Citado en TEDESCO, Juan Carlos Educación y sociedad en la Argentina (1880-1945), Ediciones Solar, Buenos Aires, [1986] 1993, p. 249.

${ }^{28}$ En Buenos Aires, el gobernador Fresco incorporó en el Reglamento General para las Escuelas Públicas la materia Religión Católica que luego se aprobó por Ley 4755/39.

${ }^{29}$ Loris Zanatta incluye a este listado la provincia de Corrientes y el clérigo José J. Del Col asegura que se daba religión en Corrientes, Jujuy y Mendoza. En ambos casos, desconocemos cuál es la normativa a la que hacen referencia los autores. DEL COL, José Juan, La dimensión religiosa..., cit.; ZANATTA, Loris Del Estado liberal a la nación católica, Universidad Nacional de Quilmes, Bernal, 1996. 
Gustavo Martínez Zuviría, impusieron la Religión Católica por Decreto 18411 en todo el país. En los fundamentos del Decreto se decía elogiosamente que la Ley 1420 se había apartado "notablemente de la ley francesa de 1882", la cual en su artículo segundo disponía que la enseñanza religiosa se impartiese "fuera de los edificios escolares", mientras que la 1420 proponía que se diese dentro de las escuelas públicas. Se reconocía además que si bien la Ley 1420 no había abolido la ER en las escuelas, "al fijarle un horario inconveniente la ha hecho imposible $\mathrm{y}$ ha dado pie a interpretaciones tendenciosas, que ha acabado por hacer de la escuela argentina una escuela prácticamente atea". En el primer artículo del Decreto se disponía: “En todas las escuelas públicas, de enseñanza primaria, post primaria, secundaria y especial, la enseñanza de la Religión Católica será impartida como materia ordinaria de los respectivos planes de estudio". Quedaban excluidos aquellos educandos cuyos padres manifestasen su oposición por pertenecer a otra religión, a quienes se les brindaría Instrucción Moral. En el segundo ítem se decía que los docentes encargados de la enseñanza de la Religión Católica serían designados por el Gobierno y autorizados por la autoridad eclesiástica. En el artículo cuarto se dispuso que la norma comprendiese a los establecimientos de enseñanza media y especial dependientes de las Universidades Nacionales, así como a las escuelas primarias nacionales. En las provincias se adecuó la normativa o bien se sancionaron nuevas leyes incluyendo ER dentro del HC. Un clérigo resumía, elogiando la norma, que se había dispuesto "enseñanza católica para los católicos; y enseñanza moral laica para los liberales, protestantes, israelitas y musulmanes". ${ }^{30}$

Después de ganar las elecciones presidenciales en 1946, Juan Domingo Perón continuó esta alianza con la Iglesia Católica y ratificó por Ley 12978/47 el Decreto. $^{31}$ En 1954 Perón decidió, por distintas razones, enfrentarse con la Iglesia y en 1955 el Congreso suprimió por Ley 14401 la enseñanza de la Religión Católica en todo el país. En septiembre de ese año Perón fue víctima de un golpe de Estado, organizado, entre otros, por un sector del socialismo, las Fuerzas Armadas y la Iglesia Católica.

Durante la autodenominada "Revolución Libertadora" (1955-1958) el ministro de educación fue el católico Atilio Dell'Oro Maini. En esos años, dirigentes como los socialistas suponían que una vez derrocado Perón, el proceso de laicización iba a consolidarse y profundizarse en todo el territorio. ${ }^{32}$ Previsiblemente, la educación no se volvió automáticamente laica. La

\footnotetext{
${ }^{30}$ FURLONG, Guillermo La tradición religiosa..., cit. p. 123.

${ }^{31}$ Sobre la relación de Perón con la Iglesia, ver: CAIMARI, Lila Perón y la Iglesia Católica. Religión, Estado y Sociedad en la Argentina. 1943-1955, Ariel, Buenos Aires, 1995.

32 RODRIGUEZ, Laura Graciela "Educación, laicismo y socialismo en la Argentina: las organizaciones de maestros y profesores entre 1955 y 1983", Historia Caribe, vol. 12, núm. 30, pp. 177-208.
} 
investigadora Puiggrós ha señalado que, si bien el gobierno pudo avanzar con el proceso de "desperonización" eliminando la simbología peronista de los textos, los planes de estudio y el calendario escolar, "[...] en la escuela persistía casi intacto el viejo discurso normalista mechado con enunciados católicos. Los retratos de Sarmiento y Mitre convivían con las imágenes de la Virgen de Luján". ${ }^{33}$ Así también, hubo sacerdotes, militares y civiles que solicitaron que se re instaurara la educación católica en todo el país, sin éxito, aunque en provincias como Córdoba se restituyeron rápidamente las leyes anteriores. ${ }^{34}$

En esa época, los ex Territorios Nacionales del sur y uno del norte provincializados en los años de 1950- definieron en sus CP que la educación sería laica: Chubut (1957), Neuquén (1957), Río Negro (1957) y Chaco (1958). ${ }^{35}$ En otro ex Territorio del norte, Misiones, se definió la educación laica por Decreto 170/57. En 1958, el presidente Arturo Frondizi y su ministro de educación, el entrerriano católico Luis Rafael Mac Kay, aprobaron para las escuelas primarias de Capital Federal el programa que había incluido nuevamente el ítem "Noción de Dios. Deberes para con Él”. ${ }^{36}$

En otro ex Territorio Nacional, La Pampa, se sancionó la CP (1960) que indicaba que la ER debía realizarse fuera del HC y en Santa Cruz se sancionó la

\footnotetext{
33 PUIGGRÓS, Adriana Qué pasó en la educación argentina, Galerna, Buenos Aires, 2006, p. 148.

${ }_{34}$ En Córdoba se restituyó en 1956 la Ley 1426 de 1896 por Decreto 117 y al año siguiente se dispuso que se impartiese Religión solo media hora, lo que provocó las protestas de la jerarquía eclesiástica. TACH, César "Partidos y pactos políticos en la Córdoba Libertadora (1955-1958)", Revista Estudios, núm 3, pp. 17-30. En esa provincia se instauró la ER también en la secundaria. El Decreto Ley 846 de 1963 de Creación del Consejo de Enseñanza Media, Especial y Superior se dispuso en el art. 4: "La enseñanza de la religión católica será impartida dentro del horario normal de clases, durante dos horas por semana como mínimo, por personas y con programas debidamente aceptados por la autoridad eclesiástica. 5. La enseñanza especial de moral, con igual exigencia de mínimo horario, para aquellos educandos cuyos padres solicitaren expresamente". En la provincia de Buenos Aires se intentó volver a instaurar la enseñanza católica, sin éxito. PETITTI, Mara "La enseñanza católica en la escuela primaria bonaerense en un contexto de transformaciones aceleradas (1946-1962)", VII Congreso Regional de Historia e Historiografía, Santa Fe, 18 al 20 mayo 2017, Universidad Nacional del Litoral; FERREYRA, Silvana G. Socialismo y antiperonismo: el Partido Socialista Democrático. Transformación partidaria y dinámica política en tiempos de proscripción (Provincia de Buenos Aires, 1955-1966), Tesis Doctorado Interuniversitario en Historia, Universidad Nacional de Mar del Plata, Mar del Plata, 2012, p. 225.

${ }^{35}$ Chubut, CP (1957), art. 107, inc. b: "La enseñanza oficial será obligatoria... laica"; Neuquén, CP (1957), art. 3: "Neuquén es una provincia... laica"; Río Negro, CP (1957), art. 153: "La enseñanza primaria y técnica complementaria que se imparta e las escuelas oficiales será gratuita, integral, laica y accesible a todos los habitantes de la provincia"; Chaco, CP (1958), art. 79: “Todos los habitantes de la provincia tienen derecho a la educación. La que ella imparta será gratuita, laica, integral, regional"

${ }^{36}$ RODRÍGUEZ, Laura Graciela "Las ideas católicas sobre la educación en los años de 1960 y 1970. El caso del CONSUDEC", en CANCINO, Hugo et. al. (comp.) Miradas desde la Historia social y la Historia intelectual. América Latina en sus culturas: de los procesos independistas a la globalización, Centro de Estudios Históricos Carlos Segretti, Córdoba, 2012, pp. 889- 904.
} 
Ley de Educación 263 que definía que debía impartirse ER dentro del HC. ${ }^{37}$ En Tucumán y Catamarca se sancionaron leyes de educación (2007 de 1960 y 2027 de 1961) que establecían, en la primera, ER dentro del horario escolar y en la segunda la "religión católica apostólica y romana". ${ }^{38}$ En Salta y Jujuy se había dispuesto la ER fuera del HC (1956), pero en 1962 se firmaron sendos Decretos que reimplantaban la ER dentro del HC.

En 1966 se produjo el quinto golpe de Estado encabezado por el general Juan Carlos Onganía. Dos años después, el encargado de la cartera, José Mariano Astigueta, anunció que se derogaría la Ley 1420 y dio a conocer el anteproyecto de la nueva Ley de Educación, escrito por importantes intelectuales católicos. Los componentes religiosos y privatistas de la norma fueron rechazados por los sindicatos de maestros y funcionarios del mismo gobierno, así que debió ser abandonada. ${ }^{39}$ A fines de 1972, el ministro de educación Gustavo Malek, dio a conocer los nuevos programas para el nivel primario en Capital Federal y el Territorio Nacional de Tierra del Fuego, que provocaron la indignación de la jerarquía eclesiástica. Los sacerdotes afirmaban que se habían suprimido de los programas vigentes desde 1961, todos los contenidos referidos a la moral y a Dios. Específicamente, se había eliminado el ítem "Noción de Dios. Deberes para con Él". Lo "extraordinariamente curioso", reclamaban los católicos, era que se hizo en "total silencio", sin consultar ni a los docentes ni a "los padres de familia afectados". Este "currículum ateo" restauraba "el más crudo y gélido ateísmo teórico y práctico en las aulas de las escuelas de jurisdicción nacional". ${ }^{40} \mathrm{El}$ clérigo empleaba un tono apocalíptico y sentenció: “No lloren mañana hipócritamente sobre las violentas consecuencias

\footnotetext{
${ }^{37}$ La Pampa, CP (1960), art. 20, inc. d: “Podrá impartirse enseñanza religiosa en las escuelas públicas a los alumnos que opten por ella...con posterioridad a las horas de clase oficial"; Santa Cruz Santa Cruz, Ley 263 (1961), art. 17: "En todos los establecimientos oficiales provinciales de enseñanza primaria y secundaria, se destinará la última hora de clase, dos veces por semana, para la instrucción religiosa de los alumnos. La instrucción religiosa será optativa y electiva".

${ }^{38}$ En Tucumán la Ley 3007 (1960) en su art 12 definía: "La formación espiritual del educando se procurará mediante la enseñanza de la religión por la que optaren los padres: en caso de negativa o de falta de elección de estos, se enseñará moral. En uno u otro caso las clases se darán durante los horarios que correspondan y como parte integrante de los respectivos planes de estudio". En Catamarca, el artículo 3 de la Ley 2027 sancionada por la Legislatura en 1958 y promulgada por el Poder Ejecutivo provincial el 28 de febrero de 1961 establecía que "En las escuelas fiscales de la provincia, la formación moral y espiritual se hará sobre la base de la enseñanza de la religión católica apostólica y romana en sus principios esenciales. La misma será optativa, no imponiéndose a los niños cuyos padres manifiesten expresamente su voluntad contraria. En este caso, deberá impartirse enseñanza de moral".

39 RODRÍGUEZ, Laura Graciela "Los católicos desarrollistas en Argentina. Educación y planeamiento en los años de 1960", Diálogos, vol. 17, núm. 1, pp. 155- 184.

${ }^{40}$ Citado en RODRÍGUEZ, Laura Graciela “Las ideas católicas...", cit., p. 895.
} 
que generaciones crecidas en aulas sin Dios desencadenen en nuestra sociedad". ${ }^{41}$

La mencionada dictadura de la "Revolución Argentina" finalizó en 1973 con la vuelta del Partido Justicialista al poder y la reelección de Perón, quien mantuvo sin cambios la legislación en relación a re incorporar la religión católica en las escuelas públicas. ${ }^{42}$ Este gobierno democrático fue interrumpido por el sexto y último golpe de Estado ocurrido el 24 de marzo de 1976, que dio inicio a la dictadura más sangrienta del país y la región. Ese mismo año, en la provincia de Santiago del Estero se firmó un Decreto (491/76) por el cual se implantaba la ER, provocando críticas de la prensa nacional. ${ }^{43}$ En 1978, en nombre de la "descentralización de los servicios" se sancionaron las Leyes 21809 y 21810 por las cuales se transfirieron a las provincias, la municipalidad de la ciudad de Buenos Aires y el Territorio Nacional de Tierra del Fuego la mayoría de las escuelas de enseñanza preprimaria y primaria nacionales (las "Láinez"), entre otros servicios. En total se pasaron aproximadamente 6.541 escuelas sin el presupuesto correspondiente. Esta medida perjudicó a unas jurisdicciones más que a otras. Por ejemplo, provocó un gran desequilibrio en las cuentas fiscales de Santiago del Estero, que recibió alrededor de 725 escuelas mientras que provincia de Buenos Aires recibió solo 11. Córdoba, Santa Fe, Corrientes, Salta y la municipalidad de Buenos Aires debieron hacerse cargo de más de 400 establecimientos cada una. ${ }^{44}$ Además del problema económico, la transferencia tuvo un impacto en lo curricular, porque escuelas que se regían por la Ley 1420 en relación a la ER fuera del HC, debieron adecuarse a la normativa de cada provincia en relación a ese contenido. Por otro lado, en 1979, el tercer ministro de cultura y educación, integrante de la "Corporación de Abogados Católicos", Juan R. Llerena Amadeo, intentó por segunda vez derogar la Ley 1420 con un texto similar al anterior, pero esta acción tampoco prosperó. ${ }^{45}$

\section{Las normas en tiempos democráticos (dic. 1983- dic. 2015)}

Cuando asumió la presidencia a fines de 1983, Raúl Alfonsín nombró como ministro a Carlos Alconada Aramburú, ex funcionario de Illia (1963-66). En diciembre de 1984 se dio a conocer la sanción de la Ley 23114, que convocaba a la organización de un Congreso Pedagógico Nacional. A partir de ese momento, los católicos se dedicaron a asegurarse la participación activa de todos sus

\footnotetext{
${ }^{41}$ Citado en RODRÍGUEZ, Laura Graciela “Las ideas católicas...”, cit., p. 895.

${ }^{42}$ Sobre este período, ver RODRÍGUEZ, Laura Graciela "Los católicos y la educación en el tercer peronismo (1973-1976)", Historia de la educación. Anuario, núm. 2, vol. 14, 2013, pp. 1-15,

${ }^{43}$ Acerca de las críticas, ver RODRÍGUEZ, Laura Graciela Católicos, nacionalistas y políticas educativas durante la última dictadura (1976-1983), Prohistoria, Rosario, 2011.

${ }^{44}$ RODRÍGUEZ, Laura Graciela Católicos, nacionalistas..., cit.

${ }^{45}$ RODRÍGUEZ, Laura Graciela Católicos, nacionalistas..., cit.
} 
docentes, ya que el evento era de "vital importancia por su proyección hacia una futura Ley de Educación". ${ }^{46}$ Según se recordaba en la prensa católica, eran 300 delegados de todo el país en la Asamblea, de los cuales "detectamos y contabilizamos un $33 \%$ de delegados católicos independientes, $27 \%$ de delegados identificados como justicialistas, en general más próximos a nuestra propuesta, $22 \%$ identificado con el radicalismo, más distantes en algunos temas concretos y un $8 \%$ identificado con partidos de izquierda, casi siempre en oposición". ${ }^{47}$ En efecto, uno de los más importantes distritos, la Capital Federal, había llevado una abrumadora mayoría de católicos (19 sobre 22), algunos de los cuales habían sido altos funcionarios de las últimas dictaduras.

El Congreso sesionó entre 1984 y 1988. Durante ese tiempo, cuatro provincias aprobaron nuevas $\mathrm{CP}$ que introdujeron o reafirmaron la ER dentro del HC: Jujuy (1986), Salta (1986), Córdoba (1987) y Catamarca (1988). ${ }^{48}$ En San Luis se dio sanción a la CP que contemplaba la ER fuera del horario escolar. ${ }^{49} \mathrm{Al}$ contrario, las CP de San Juan y Santiago del Estero, ambas de 1986, concluyeron que la enseñanza debía ser "no confesional" en la primera y "laica" en la segunda; y en Chubut la Ley de Educación 3146 dictaminó que fuese "laica" (1988)..$^{50}$

Acerca del Congreso Pedagógico, un cronista católico explicó que durante las sesiones se habían enfrentado por el tema religioso los representantes del norte del país y los del sur patagónico. Los delegados del sur, decía, evidenciaban "pocos nexos de unión con los salesianos, los primeros

\footnotetext{
${ }^{46}$ RODRÍGUEZ, Laura Graciela "Iglesia y educación en la Argentina durante la segunda mitad del siglo XX", Cadernos de Histórica da Educação, vol. 14, núm. 2, pp. 263-278, 2015.

${ }^{47}$ Consudec, núm. 924, junio 2000. Sobre cómo se formó el Congreso Pedagógico y las internas católicas ver FABRIS Mariano Iglesia y democracia. Avatares de la jerarquía católica en la Argentina post autoritaria (1983-1989), Prohistoria, Rosario, 2011.

${ }^{48}$ Jujuy, CP, (1986), art. 30, punto 3: "Los padres y en su caso los tutores, tienen derecho a que sus hijos o pupilos reciban la educación religiosa y moral acorde con sus propias convicciones"; Salta, CP, (1986), art. 49: "Los padres y en su caso los tutores, tienen derecho a que sus hijos o pupilos reciban en la escuela pública la educación religiosa que esté de acuerdo con sus propias convicciones"; Córdoba, CP (1987), art. 62, punto 5: "Los padres tienen derecho a que sus hijos reciban en la escuela estatal educación religiosa o moral según sus convicciones"; Catamarca, CP, (1988), art. 270: "La provincia garantizará la enseñanza religiosa en sus centros educativos de todos los niveles según el culto de los educandos".

${ }^{49}$ San Luis, CP (1987), art. 75, punto 4: "En las instituciones educativas estatales la enseñanza religiosa solo puede ser dada por los ministros o personas autorizadas de los diferentes cultos, a los alumnos de su respectiva comunión fuera de los horarios de clase".

${ }^{50}$ San Juan, CP (1986), art. 80: La enseñanza que imparte el Estado es obligatoria, gratuita, no confesional”; Santiago del Estero, CP (1986), art. 196, inc. 1: "La educación... dada por el Estado será laica"; Chubut, (1988), Ley 3146, art. 4: "Se consagra la educación oficial como laica y gratuita, popular, nacional y liberadora"
} 
en brindar educación en esas latitudes. Sus casi 40 delegados se orientaron en bloque hacia posturas de predominio estatista, con cierto aire radicalizado". ${ }^{51}$

Después del Congreso, en julio de 1989 asumió el presidente Carlos Menem (1989-1999) y su ministro fue un aliado de los católicos, Antonio Salonia (1989-1992), uno de los ideólogos de las leyes de transferencia y de educación. En Tucumán, se ratificó la ER por medio de la Ley de Educación 5996 de 1989 y la CP sancionada en 1990 (art. 123, punto 2), donde se decía: "La formación espiritual del educando se preocupará mediante la enseñanza de religión o moral. En uno u otro caso, las clases se darán en los horarios que corresponda y como parte integrante de los respectivos planes de estudio". En Santiago del Estero la Ley 5804 consagró la educación laica.

En Córdoba, en 1991, se aprobó la Ley de Educación 8113 que señalaba en el art. 7 inciso " $c$ ", que los padres tenían derecho a que sus "hijos reciban, en el ámbito de la educación pública estatal, educación religiosa". Sin embargo, una investigadora cordobesa ha afirmado que dicha enseñanza, al no formar parte de los contenidos curriculares obligatorios, quedaba supeditada a la decisión del personal directivo de la escuela y a la disposición de catequistas o ministros autorizados, que, debido a su escasez, hacía que a veces se decidiese que algunos grados o ciclos tuviesen religión y otros no, dentro de la misma escuela. ${ }^{52}$

En 1992 se dio a conocer la Ley 24049 de "Transferencia del sistema educativo nacional de la educación primaria, secundaria y terciaria a las provincias y a la municipalidad de la ciudad de Buenos Aires" que terminó el proceso de traspaso masivo de las instituciones educativas nacionales a las provincias. En esta ocasión, las jurisdicciones recibieron alrededor de 4.764 establecimientos nacionales, con las mismas consecuencias curriculares en relación a la ER que habíamos mencionado antes. Luego de los intentos fallidos durante las dos últimas dictaduras de reemplazar la Ley 1420, el 14 de abril de 1993 se sancionó la Ley Federal de Educación (24195), que fue muy elogiada por los obispos católicos, especialmente porque en su artículo sexto sostenía que el sistema educativo debía posibilitar la realización de las personas en las "dimensiones ética y religiosa", afirmando que este texto representaba "el fin de cien años de laicismo confeso". ${ }^{53}$ Más allá de estas expresiones de la Iglesia, la norma no se pronunció sobre la ER dentro o fuera del HC. Al año siguiente, las más altas autoridades eclesiásticas lograron que el ministro de la cartera, Jorge

\footnotetext{
${ }^{51}$ DEL COL, José Juan, La dimensión religiosa..., cit, p. 5.

52 MAGI, Margarita Elizabeth Enseñanza religiosa..., cit., p. 55. Lo mismo sostenía otro analista, ver GENTILE, Jorge Horacio "La educación religiosa en la provincia de Córdoba", 2010, disponible en

http://www.maritainargentina.org.ar/la_educacion_religiosa_prov_de_cordoba.htm [visitado 21 diciembre 2012]

${ }^{53}$ Citado en RODRÍGUEZ, Laura Graciela “Iglesia y educación en la Argentina..., cit., p. 271.
} 
Rodríguez, aceptase introducir cambios en la orientación claramente laicista que tenían ciertos contenidos curriculares de las ciencias naturales, las ciencias sociales y el área de formación ética y ciudadana. ${ }^{54}$

En referencia a las provincias, en Jujuy la Ley 4731 de 1993 iba en línea con la CP y afirmaba que el Estado garantizaba y posibilitaba la enseñanza de la ER. En 1994 en La Pampa se aprobó la CP con ER fuera del horario escolar, al tiempo que la CP del Chaco (1994) dictaminó la educación laica, igual que en Ciudad de Buenos Aires (1996). ${ }^{55}$ En 1995 en Salta se sancionó la Ley de Educación 6829 y a comienzos de 1997 se incluyó la materia "Religión" en los diseños curriculares. En San Juan se dispuso la Ley 6755/96 con ER fuera del HC. En Catamarca se sancionó la Ley de Educación 4843 (1995) y se dispuso la garantía de la "enseñanza religiosa en las unidades escolares (de dependencia estatal)" (art.26, inc. d). Se firmó la resolución 1566 que fijaba "Religión" para las escuelas públicas y privadas y los contenidos de la materia fueron elaborados por los delegados del Obispado provincial. ${ }^{56}$ Debido a protestas de la comunidad judía local, en 1999 el gobernador Oscar Castillo decidió dejar la asignatura como opcional, no obligatoria y a dictarse en la última hora del día viernes (ver infra).

En 1997 en la CP de Santiago del Estero se sostenía que los padres tenían derecho a que en la escuela pública sus hijos recibiesen ER (art. 71) y en 2002 se aprobó otra CP en la misma dirección, rompiendo así la tradición laicista de las décadas anteriores. En 1997 en Chaco, la Ley 4449 garantizaba la educación gratuita, laica y regional (art. 2). En 2001, la Ley 9330 de Entre Ríos, fiel a su histórica postura, definía nuevamente a la educación como obligatoria, laica y gratuita. En 2002 la Ley de Educación 6970 de la provincia de Mendoza establecía en su artículo cuarto que el Estado garantizaba la educación pública laica. Hubo varias provincias que no sancionaron sus leyes después de la Ley Federal (Chubut, Córdoba, Corrientes, Formosa, Neuquén, San Luis, Río Negro, Santa Cruz y Santa Fe), aunque debieron adecuar el sistema a los nuevos niveles creados de Educación General Básica y Polimodal.

El presidente Néstor C. Kirchner (2003-2007) tuvo un solo ministro durante su gestión, el sociólogo Daniel F. Filmus. En 2003 en Neuquén se sancionó otra CP con la educación laica y en Tucumán se aprobaron la Ley 1763 (2004) y la CP (2006) con ER. ${ }^{57}$ En mayo del 2006 se logró la aprobación de una

54 NOSIGLIA, María Catalina y ZABA, Stella Maris “El papel de la Iglesia Católica en la formulación e implementación de las políticas educativas argentinas en los '90", Anuario de la Historia de la Educación, núm. 4, 2003, pp. 61-94.

${ }^{55}$ La Capital Federal es declarada Ciudad Autónoma con la reforma constitucional de 1994.

56 MEZZADRA, Florencia Provincia de Catamarca, en RIVAS, Axel (dir.) Las provincias educativas..., cit.

${ }^{57}$ En Tucumán, hacia 2001 se anunció que se daría marcha atrás con la Ley Federal por una cuestión presupuestaria y en consecuencia, se eliminaría la materia en los Octavos y Novenos 
nueva Ley Nacional de Educación (26206) que recibió duras críticas de las autoridades de la Iglesia por no contemplar la "dimensión religiosa" en la formación, la excesiva centralización del sistema educativo, particularmente de la formación docente y la inclusión como contenido curricular obligatorio la Ley 26171 que ratificaba el "Protocolo facultativo de la Convención para la Eliminación de Toda Forma de Discriminación de la Mujer (CEDAW)".

Luego de los comicios de 2007, asumió como presidenta Cristina Fernández de Kirchner (2007-2011), quien volvió a ser elegida para el período 2011-2015. En línea con sus tradiciones, ratificaron la laicidad del sistema educativo las provincias de Entre Ríos (Ley 9890 de 2008), Chaco (6691 de 2010) y Río Negro (4819 de 2012) y la provincia más nueva del país, Tierra del Fuego, Antártida e Islas del Sur (1763 de 2014). En Tucumán se continuó la ER dentro del HC (Ley 8391 de 2010), lo mismo que en Salta (Ley 7546 de 2008), aunque en esta provincia la medida se judicializó (ver infra). En Córdoba, en el medio de importantes protestas, se acordó por primera vez la ER fuera del HC (Ley 9870 de 2010). Las provincias que aún no habían sancionado sus propias Leyes después de 2006 y hasta diciembre de 2015, eran: Corrientes, Misiones, Mendoza, San Luis y Santa Fe.

\section{Debates en el siglo XXI: la interpretación de la norma y la práctica escolar}

En este apartado nos proponemos observar, a través de distintas notas de prensa publicadas en los últimos quince años, cómo los docentes y funcionarios de justicia y educación han habilitado y/o naturalizado prácticas católicas cotidianas en las escuelas públicas, aun en provincias donde se dispuso el laicismo, es decir, más allá de las Leyes, Decretos y Constituciones.

En el año 2001 se dio una polémica por la provincia de Catamarca y la prensa católica decidió titular ese número del periódico Consudec: "Formación religiosa ¿por qué?". ${ }^{58}$ La Delegación de Asociaciones Israelitas Argentinas (DAIA) había cuestionado la inclusión de la Religión en la Ley de Educación sancionada en 1995 y en la CP de 1988. Como ya mencionamos, un estudio mostró que los contenidos de la materia Religión habían sido elaborados por los delegados del Obispado provincial, que no tuvieron en cuenta a las otras religiones. ${ }^{59}$ De todos modos, desde la prensa católica se negaba que se estuviese dando en Catamarca "catequesis católica" y se aseguraba que la

grados de la Educación General Básica. El CONSUDEC en pleno reaccionó en contra y consiguió el recambio del ministro por uno más afín que continuó con la aplicación de la Ley. LLINÁS, Paola Provincia de Tucumán, en RIVAS, Axel (dir.) Las provincias educativas..., cit. En 2002 se aprobó la materia Formación Moral/ Religión para el 7mo, 8vo y 9no año de la EGB (Res. 1115).

${ }^{58}$ Consudec, núm. 908, junio 2001.

${ }^{59}$ MEZZADRA, Florencia Provincia de Catamarca..., cit. 
materia seguía una "concepción más amplia" y por tanto su eliminación "contradecía la constitución provincial". ${ }^{60}$ Lo extraño, continuaba, era que se cuestionaba solamente a Catamarca, cuando las demás provincias del Noroeste argentino (Tucumán, Salta, Jujuy y Santiago del Estero) también garantizaban, y de hecho impartían, enseñanza religiosa en las escuelas públicas, "pero nadie las acusó falsamente de discriminatorias, ni se presionó tanto para que se erradicara la religión de las escuelas". ${ }^{61}$ El objetivo central, en definitiva, era "expulsar a Dios de las escuelas". En ese mismo tono se pronunció la revista católica Criterio, donde se agregaba que la Ley Federal pedía "tener presente la dimensión religiosa en la educación", por lo que cada escuela incluso podía decidir cuál religión impartir. ${ }^{62} \mathrm{El}$ conflicto concluyó formalmente con el acuerdo entre los referentes de las diversas religiones que la asignatura sería opcional, no obligatoria y dictada en la última hora del día viernes. Sin embargo, en la mayoría de las escuelas catamarqueñas se siguió dictando catequesis. ${ }^{63}$ Una ex funcionaria explicó que "en Catamarca se da religión, no porque esté en el currículum, sino porque el docente es católico y muchos empiezan las mañanas con un rezo". ${ }^{64}$

En Salta, luego de que se sancionara una nueva Ley que dispuso la ER dentro del HC en 2008, la Asociación por los Derechos Civiles y un grupo de padres iniciaron una acción de amparo colectiva en 2010 contra el Ministerio de Educación, pidiendo que se garantizara la neutralidad del Estado en materia religiosa y que cesaran las prácticas religiosas cotidianas como el rezo inicial al entrar, la oración dentro del aula y la bendición de los alimentos. En marzo de 2012 un juez dio lugar al amparo y ordenó al Estado adoptar las medidas necesarias para el cese la imposición de la religión católica en la primaria. En julio, los jueces de la Corte provincial dijeron que la Ley era constitucional y que debía garantizarse tanto la enseñanza religiosa como espacios alternativos de formación a los alumnos que tuviesen otras convicciones. Los jueces salteños afirmaron que la libertad religiosa aplicada al ámbito de la enseñanza escolar, no debía ni podía ser entendida en el sentido de la exclusión de todo lo religioso, ya que la Argentina estaba "jurídicamente estructurada desde su fundación como una nación católica apostólica romana" y la provincia de Salta en particular tenía "una población mayoritariamente católica" ${ }^{65} \mathrm{El}$ caso fue elevado a la Corte Suprema de la Nación, la cual en un fallo dividido del 12 de

\footnotetext{
${ }^{60}$ Consudec, núm. 908, 2001.

${ }^{61}$ En base a nuestro estudio, las provincias que también tenían ER, además de las mencionadas, eran Córdoba (ER dentro del HC) y San Juan (ER fuera del HC). La CP de La Pampa establecía ER fuera del HC pero la Ley no se pronunciaba sobre esa cuestión.

${ }^{62}$ Criterio, núm. 2263, 2001

${ }^{63}$ MEZZADRA, Florencia Provincia de Catamarca..., cit.

${ }^{64}$ Citado en MEZZADRA, Florencia Provincia de Catamarca..., cit., p. 87.

$65 \mathrm{http} / / / \mathrm{www}$.primerafuente.com.ar/noticia/782929-educacion-y-religion-la-justicia-decide-ensalta-y-en-mendoza [consultado el 5 de diciembre de 2016]
} 
diciembre de 2017 dictaminó por mayoría que era inconstitucional el inciso "ñ" del art. 27 de la ley 7546, es decir, la ER dentro del HC. Inmediatamente, el gobernador anunció que se continuaría impartiendo ER pero fuera del HC.

En Tucumán, donde hay enseñanza religiosa dentro del horario escolar, la prensa informó que las autoridades del Instituto Nacional por la Discriminación, la Xenofobia y el Racismo (INADI) hacía varios años que estaban recibiendo denuncias por la discriminación religiosa en las escuelas. ${ }^{66}$ Distintos padres se quejaron porque en las escuelas las directoras hacían rezar a los alumnos el Avemaría antes de entrar al aula o en otras se representaba el Vía Crucis en Semana Santa dentro del establecimiento. Otros expresaron que dentro de la materia alternativa "Formación Moral", una docente les hablaba de Jesús sin tener en cuenta que había en la clase alumnos judíos y adventistas. Consultada por la prensa, una docente explicó que el Ministerio de Educación les exigía el título de "maestra en religión" para dar "Moral". Agregó que los docentes de esa asignatura eran supervisados por la Junta Arquidiocesana de Educación Católica. Recientemente, en base al fallo de la Corte Suprema sobre la enseñanza religiosa en Salta, un grupo de padres presentó un recurso de amparo ante la Justicia para que se dejara de impartir religión en el horario de clase, dado que hoy sería la "única provincia del país" en la que "todavía se enseña religión católica apostólica romana en las escuelas públicas". ${ }^{67}$

En 2013 la Asamblea Permanente por los Derechos Humanos (APDH) de San Rafael, provincia de Mendoza, presentó un amparo para que se retirasen del calendario escolar las celebraciones religiosas en las escuelas públicas. Cuestionaban la inclusión de las conmemoraciones católicas del Patrón Santiago (25 de julio) y del Día de la Virgen del Carmen de Cuyo (8 de septiembre). Ante la negativa de la Dirección General de Escuelas, la APDH optó por la vía judicial, reclamando que se declarara inconstitucional la resolución 1626 que había sido emitida durante la última dictadura. En 2015 la Suprema Corte provincial avaló la inclusión de dichas fechas religiosas. El abogado de la APDH, Carlos Lombardi, dijo que el fallo era de una "intransigencia brutal", "muy pobre" en sus argumentos, basándose en que las tradiciones católicas "no se tocaban" porque "formaban parte de la cultura". ${ }^{68}$

En marzo de 2013, el jefe de gobierno de la Ciudad Autónoma de Buenos Aires, Mauricio Macri, firmó un decreto para que el día de la asunción de Jorge Bergoglio como el nuevo Papa, fuese feriado en el turno de la mañana en todas

\footnotetext{
${ }^{66} \mathrm{http}: / /$ www.primerafuente.com.ar/noticia/009155-denuncian-que-los-rituales-catolicos-en-lasescuelas-laicas-generan-maltrato [consultado el 1 de diciembre de 2016]

67 http://www.lavoz.com.ar/ciudadanos/tucuman-presentaron-un-amparo-para-que-no-seensene-religion-en-las-escuelas-publicas [consultado el 5 de mayo de 2018]

68 https://www.diariouno.com.ar/pais/tras-el-aval-la-suprema-corte-las-fiestas-religiosascolegios-el-fallo-es-una-intransigencia-brutal-20150924-n49004.html [consultado el 1 de diciembre de 2016]
} 
las escuelas. ${ }^{69} \mathrm{Su}$ ministro de educación, Esteban Bullrich, justificó la medida porque la Ciudad consideraba que la elección del Papa Francisco era "uno de los acontecimientos más importantes que se han producido a lo largo de toda la historia argentina" y que excedía, "largamente, el fenómeno religioso". Agregaba que "se han sumado a esta alegría todos los argentinos de buena voluntad en un arco que integran con igual fuerza y valores los católicos y los no católicos, los creyentes de cualquier credo o religión y los que no profesan ninguna". En diciembre de 2015 Macri fue elegido presidente y designó ministro a Bullrich. En abril de 2017 el presbítero Juan C. Mendoza de la ciudad de Esquina (Corrientes), expresó que le había pedido a Bullrich que se volviese "a impartir la educación católica en las aulas", ya que ahora no era posible. ${ }^{70} \mathrm{El}$ clérigo argumentó que “Está pasando lo que está pasando porque hemos sacado a Dios de nuestras vidas, hemos sacado los crucifijos de los juzgados, todos los signos de Dios los vamos sacando y hay que recuperarlos". El ministro le contestó que "Por más que soy católico, trato de ser un apóstol y buen discípulo, sí creo que en las escuelas debemos enseñar otras religiones también, que también tienen lecciones para aprender". En suma, en pleno siglo XXI el funcionario admitió que estaría dispuesto a incluir nuevamente a nivel nacional la enseñanza religiosa dentro del horario de clase. ${ }^{71}$

\section{Reflexiones finales}

En este artículo hicimos foco en uno de los múltiples aspectos de la religiosidad o la laicidad, como es la dimensión jurídica y la inclusión de la enseñanza religiosa o la educación laica en las Constituciones Provinciales, Leyes y Decretos nacionales y provinciales de educación. Buscamos efectuar un estudio de largo plazo que nos permitiese identificar los cambios y continuidades en relación a la enseñanza religiosa o la educación laica en las escuelas públicas

\footnotetext{
69 http://www.lanacion.com.ar/1563694-decretan-asueto-escolar-en-capital-por-la-asuncion-delpapa [consultado el 3 de diciembre de 2016]

70 Clarín, 25 abril 2017.

${ }^{71}$ En las Universidades Nacionales se vienen haciendo denuncias por la presencia de imágenes católicas. En la Universidad Nacional de La Pampa, en 2014 un grupo de feministas presentó una nota para pedir que se retirase la Virgen de Luján que estaba en la planta baja del edificio. El pedido provocó la reacción de la jerarquía católica y militantes que recogieron firmas para evitar la remoción. A lo largo de 2018 se sucedieron más hechos de este tipo: en la Facultad de Medicina de la UBA los alumnos taparon la imagen de la Virgen; en la Facultad de Derecho de la Universidad Nacional de Córdoba los estudiantes sacaron la imagen de la Virgen al grito "Iglesia, Estado, asunto separado"; en la Facultad de Filosofía de la Universidad Nacional de San Juan dos grupos se enfrentaron por la imagen de la Virgen ubicada en el hall. El escritor Ricardo Piglia contaba una anécdota similar ocurrida en los años de 1960 en la Facultad de Humanidades de la Universidad Nacional de La Plata, por la imagen del Cristo Crucificado ubicado en el Aula Magna. PIGLIA, Ricardo Los diarios de Emilio Renzi. Años de formación, Anagrama, Barcelona, 2015, p. 90.
} 
estatales de nivel primario, tanto a nivel nacional como dentro de una misma provincia, desde 1884 hasta 2015.

Desarrollamos tres hipótesis vinculadas. Mostramos, en primer lugar, que de las tres leyes nacionales, solo la primera, la 1420/84 dispuso enseñanza religiosa fuera del horario escolar. Los testimonios aseguran que fue de difícil implementación porque no había espacio físico en las escuelas para impartirla y esto hizo que de hecho, la educación en la Capital Federal y los Territorios Nacionales fuese neutra en materia religiosa. La segunda Ley nacional, la Ley Federal de 1993 contempló la "dimensión religiosa" en la educación pero no dispuso su enseñanza, y la tercera norma de 2006 resultó la más neutra en materia religiosa.

En segundo término, vimos que más allá de la normativa nacional, las provincias han ejercido en los hechos, una plena autonomía para legislar sobre la ER o la educación laica en sus jurisdicciones. Al observar la normativa sancionada después de 1884 y hasta diciembre de 2015, se puede advertir la heterogeneidad que ha coexistido en el país (ver Cuadro). Las provincias que incluyeron la educación laica en los textos de sus CP o de sus Leyes de Educación en algún momento de su historia, fueron casi todas las del sur (Neuquén, Río Negro, Chubut y Tierra del Fuego); dos del noroeste (Jujuy y Santiago del Estero); dos del noreste (Chaco y Entre Ríos); y dos de Cuyo (Mendoza y San Juan). Como vimos, la provincia de Santa Fe tuvo una breve experiencia con una Ley que declaró la educación laica entre 1934 y 1935.

Las provincias que dispusieron la enseñanza de la religión o Religión Católica en las escuelas públicas dentro del horario escolar alguna vez en su legislación (sin contar el período 1943-1955), fueron todas las de noroeste (Jujuy, Salta, Tucumán, Catamarca y Santiago del Estero); una del sur (Santa Cruz) y tres de la región pampeana (Buenos Aires, Córdoba y Santa Fe). Entre las jurisdicciones que ordenaron la enseñanza de la religión fuera del horario escolar alguna vez en su normativa, estuvieron tres del noroeste (Jujuy, Salta y Catamarca); dos de la región pampeana (Córdoba y La Pampa); y una de Cuyo (San Juan). Las provincias que evitaron pronunciarse por el laicismo o la religión (neutras) en algún año del período estudiado, fueron: dos del noroeste (Catamarca y Santiago del Estero); tres de Cuyo (San Juan, San Luis y La Rioja); dos de la región noreste (Formosa y Misiones); dos de la región pampeana (Buenos Aires y La Pampa); y dos del sur (Chubut y Santa Cruz). Como se podrá apreciar, la variedad de posturas en relación a la laicidad y la religiosidad se fue dando incluso dentro de una misma provincia. Por ejemplo, en San Juan hubo enseñanza no confesional en 1986, educación religiosa fuera del horario de clase (1996) y educación neutra en 2015. En Santiago del Estero se dispuso educación laica (1924), enseñanza religiosa (1976 y 1989) y neutra (2007). 
Por último, hemos ilustrado, a través de una pequeña muestra, cuáles han sido las prácticas católicas cotidianas en ciertas escuelas, independientemente de la normativa sancionada; y qué pronunciamientos públicos han hecho funcionarios judiciales y de educación sobre el laicismo y la enseñanza religiosa en los últimos quince años. Observamos que en provincias donde regía la educación laica como Mendoza, se encontraban incluidas en el calendario escolar festividades católicas; y en la Ciudad de Buenos Aires se dispuso un feriado por la asunción del jefe máximo del Vaticano. En Catamarca, Salta y Tucumán se iniciaban las clases con un rezo y en algunas se oraba en el aula, se bendecían los alimentos, y/o se representaba el Vía Crucis en Semana Santa dentro del establecimiento. La materia alternativa a la ER era Moral pero en una de las provincias los padres denunciaron que allí también se daba catequesis. Del lado de los funcionarios judiciales, en general fallaron a favor de conservar las "tradiciones católicas" de cada jurisdicción y la Corte Suprema de Nación habilitó la posibilidad de que se impartiese enseñanza religiosa fuera del horario escolar. Recientemente, un alto funcionario nacional admitió que estaría de acuerdo con la re implantación de la enseñanza religiosa en las escuelas públicas, aclarando que en la nueva asignatura se darían "todas las religiones".

En resumen, si bien podemos afirmar que en la Argentina predominó mayoritariamente la idea de que en la escuela pública no debía impartirse catequesis católica, esta historia se complejiza cuando observamos lo sucedido en cada provincia, dado que a lo largo de más de un siglo, sus autoridades han tomado distintas decisiones en materia de laicidad o religiosidad en forma autónoma del gobierno nacional. En la actualidad, vimos que las provincias que tenían enseñanza religiosa dentro del horario escolar, hoy ya no la incluyen- a excepción de una-, aunque es preciso investigar con mayor profundidad las prácticas cotidianas que se dan dentro de las instituciones en relación a este tema. Cabe agregar que el año 2018 estuvo marcado por los intentos de modificar leyes y de avanzar con la laicidad, aunque estos intentos pusieron en evidencia la importante presencia de funcionarios estatales que hoy como ayer, profesan en el ámbito privado la religión católica u otra religión, y deciden las políticas públicas en función de esa creencia. ${ }^{72}$

\footnotetext{
${ }_{72}$ Por lo menos hasta septiembre de 2018, se dieron tres hechos: por un lado y como apuntamos al inicio, se presentaron en el Congreso de la Nación varios proyectos que proponen la separación del Estado y la Iglesia y la suspensión de todo financiamiento estatal; por otro lado, en junio y agosto se discutió por primera vez en la historia el proyecto de ley de despenalización del aborto en el Congreso, y aunque no se logró su aprobación, tuvo un gran impacto en la escena pública. En líneas generales, la mayoría de los senadores del noroeste se reconocieron católicos y votaron por la negativa y una importante cantidad de senadores de las provincias del sur, fieles a su tradición laicista, se pronunciaron a favor. El tercer hecho fue en septiembre, cuando un grupo de diputados firmó un dictamen donde se declaró a la Ley de
} 
Cuadro: Leyes, Decretos y Constituciones Provinciales (1884-dic.2015) ${ }^{73}$

\begin{tabular}{|c|c|c|c|c|c|c|}
\hline & $1884-1930$ & 1931- 1943 & $\begin{array}{l}\text { Dic. 1943- } \\
\text { Sept. } 1955\end{array}$ & Oct. 1955-1992 & 1993-2005 & 2006-2015 \\
\hline $\begin{array}{l}\text { Leyes } \\
\text { Nacionales }\end{array}$ & $\begin{array}{l}\text { Ley de } \\
\text { Educación } \\
1420 \text { de } \\
1884: \text { ER } \\
\text { fuera del } \\
\text { HC }\end{array}$ & & $\begin{array}{l}\text { Decreto } \\
\text { 18411/43: } \\
\text { ER dentro } \\
\text { del HC } \\
\text { Ley } \\
\text { 12978/47: } \\
\text { ER dentro } \\
\text { del HC } \\
\text { Ley 14401 } \\
\text { suprime } \\
\text { ER }\end{array}$ & & $\begin{array}{l}\text { Ley Federal } \\
\text { de Educación } \\
24195 \text { (1993) }\end{array}$ & $\begin{array}{l}\text { Ley de } \\
\text { Educación } \\
\text { Nacional } \\
26206 \\
(2006)\end{array}$ \\
\hline CABA & & & & & CP (1996): EL & \\
\hline $\begin{array}{l}\text { Buenos } \\
\text { Aires }\end{array}$ & $\begin{array}{l}\text { CP (1889) } \\
\text { Ley 2934 } \\
(1905): \\
\text { omite ER } \\
\text { dispuesta } \\
\text { en la Ley } \\
988 \text { de } \\
1875\end{array}$ & $\begin{array}{l}\text { En } 1936 \text { se } \\
\text { introduce la } \\
\text { ER y por } \\
\text { Ley } 4755 \\
\text { (1939) se } \\
\text { ratifica }\end{array}$ & $\begin{array}{l}\text { Ley } 5650 \\
\text { (1951): ER } \\
\text { En } 1954 \text { se } \\
\text { suprime el } \\
\text { art. } 9 \text { de la } \\
\text { Ley } \\
5650 / 51 \text { de } \\
\text { ER }\end{array}$ & & $\begin{array}{l}\text { CP (1994) } \\
\text { Ley } 11612 \\
(1995)\end{array}$ & $\begin{array}{l}\text { Ley } 13688 \\
(2007)\end{array}$ \\
\hline Catamarca & $\begin{array}{l}\text { CP (1895) } \\
\text { Ley de } \\
1900\end{array}$ & $\begin{array}{l}\text { Decreto } 403 \\
\text { (1936): ER }\end{array}$ & $\begin{array}{l}\text { Decreto } \\
1194 \\
(1944): \text { ER }\end{array}$ & $\begin{array}{l}\text { Ley } 2027 \text { (1961): } \\
\text { ER } \\
\text { CP (1966): ER } \\
\text { CP (1988): ER }\end{array}$ & $\begin{array}{l}\text { Ley } 4843 \\
\text { (1995): ER, } \\
\text { resolución en } \\
1999 \text { deja ER } \\
\text { dentro del } \\
\text { HC pero } \\
\text { optativa }\end{array}$ & $\begin{array}{l}\text { Ley } 5381 \\
(2013)\end{array}$ \\
\hline Chaco & & & $\begin{array}{l}\text { Ley } 24 \\
\text { (1954): ER } \\
\text { Ley } 89 \\
\text { (1954): ER } \\
\text { Ley 112 } \\
\text { (1955): ER }\end{array}$ & $\begin{array}{l}\text { CP (1958): EL } \\
\text { Ley } 2214 \text { (1978) }\end{array}$ & $\begin{array}{l}\text { CP (1994): EL } \\
\text { Ley 4449 } \\
\text { (1997): EL }\end{array}$ & $\begin{array}{l}\text { Ley 6691 } \\
\text { (2010): EL }\end{array}$ \\
\hline Chubut & & & & $\begin{array}{l}\text { CP (1957):EL } \\
\text { Ley } 40 \text { (1958) } \\
\text { Ley } 3146 \text { (1988): } \\
\text { EL }\end{array}$ & CP (1994) & $\begin{array}{l}\text { Ley 91 } \\
(2010)\end{array}$ \\
\hline Córdoba & $\begin{array}{l}\text { Ley1426 } \\
\text { (1896): ER } \\
\text { CP (1900) } \\
\text { Ley 2023 } \\
\text { (1908): ER } \\
\text { CP (1923): }\end{array}$ & & & $\begin{array}{l}\text { En } 1956 \text { se } \\
\text { restituye la Ley } \\
1426 \text { por Decreto } \\
117 \\
\text { CP }(1987) \text { ER } \\
\text { Ley } 8113(1991) \\
\end{array}$ & & $\begin{array}{l}\text { Ley } 9870 \\
\text { (2010): ER } \\
\text { fuera del } \\
\text { HC }\end{array}$ \\
\hline
\end{tabular}

Educación Sexual Integral, entre otras cosas, de carácter "laico, científico y respetuoso de la diversidad sexual y de género".

${ }^{73}$ En este cuadro hemos omitido todas las normas que se refieren a educación que no mencionan específicamente a la ER o la educación laica. Asimismo, mencionamos solo el contenido de las Leyes, Decretos y Constituciones Provinciales y no de otro tipo de normas como Resoluciones, Directivas, etc. 


\begin{tabular}{|c|c|c|c|c|c|c|}
\hline & ER & & & ER & & \\
\hline Corrientes & $\begin{array}{l}\text { Ley }(1886) \\
\text { CP }(1889) \\
\text { Ley } 387 \\
(1901)\end{array}$ & & $\begin{array}{l}\text { Decreto } 37 \\
\text { (1944): ER } \\
\text { Ley 1576: } \\
(1951)\end{array}$ & & CР 1993 & \\
\hline Entre Ríos & $\begin{array}{l}\text { CP (1885): } \\
\text { EL }\end{array}$ & $\begin{array}{l}\text { CP (1933): } \\
\text { EL }\end{array}$ & & Ley 7711 (1986) & $\begin{array}{l}\text { Ley 9330 } \\
\text { (2001): EL }\end{array}$ & $\begin{array}{l}\text { CP (2008): } \\
\text { EL } \\
\text { Ley } 9890 \\
(2008)\end{array}$ \\
\hline Formosa & & & & $\begin{array}{l}\text { CP (1957) } \\
\text { Ley nivel primario } \\
153 \text { (1960) } \\
\text { Ley nivel primario } \\
375 \text { (1984) } \\
\text { CP (1991) }\end{array}$ & $\begin{array}{l}\text { Ley } 1470 \\
(2005)\end{array}$ & $\begin{array}{l}\text { Ley } 1613 \\
\text { (2014) }\end{array}$ \\
\hline Jujuy & $\begin{array}{l}\text { CP (1895) } \\
\text { Ley (1895) }\end{array}$ & & $\begin{array}{l}\text { Ley } 1710 \\
\text { (1946): ER }\end{array}$ & $\begin{array}{l}\text { Decretos } 40 \text { y } 41 \\
\text { (1956) ER fuera } \\
\text { del HC } \\
\text { Decreto Ley } 5 \\
\text { (1962): restituye la } \\
\text { Ley 1710 de 1946: } \\
\text { ER } \\
\text { CP (1986): ER }\end{array}$ & $\begin{array}{l}\text { Ley } 4731 \\
\text { (1993): ER }\end{array}$ & $\begin{array}{l}\text { Ley } 5807 \\
\text { (2014): EL }\end{array}$ \\
\hline La Pampa & & & $\begin{array}{l}\text { Ley } 80 \\
\text { (1954): ER } \\
\text { Ley 124 } \\
\text { (1955): } \\
\text { deroga la } \\
\text { ER }\end{array}$ & $\begin{array}{l}\text { CP (1960): ER } \\
\text { fuera del HC }\end{array}$ & $\begin{array}{l}\text { CP (1994): } \\
\text { ER fuera del } \\
\text { HC } \\
\text { Ley } 1682 \\
(1996)\end{array}$ & $\begin{array}{l}\text { Ley } 2511 \\
\text { (2009) }\end{array}$ \\
\hline La Rioja & $\begin{array}{l}\text { Ley } 122 \\
(1910)\end{array}$ & & $\begin{array}{l}\text { Ley } 1003 \\
\text { (1946): ER }\end{array}$ & CP (1986) & $\begin{array}{l}\text { Ley } 6660 \\
(1998)\end{array}$ & $\begin{array}{l}\text { Ley } 8678 \\
(2009)\end{array}$ \\
\hline Mendoza & $\begin{array}{l}\text { Ley } 37 \\
(1897) \\
\text { CP (1900) } \\
\text { CP (1916): } \\
\text { EL }\end{array}$ & & & & $\begin{array}{l}\text { Ley 6970 } \\
\text { (2002):EL }\end{array}$ & \\
\hline Misiones & & & & $\begin{array}{l}\text { Decreto } 170 \\
\text { (1957): EL } \\
\text { CP 1958 } \\
\text { Ley } 986 \text { (1978) }\end{array}$ & $\begin{array}{l}\text { Ley } 4026 \\
(2003)\end{array}$ & \\
\hline Neuquén & & & & $\begin{array}{l}\text { CP (1957): EL } \\
\text { Ley } 242 \text { (1961) } \\
\text { Ley } 4947 \text { (1991) }\end{array}$ & CP (2003): EL & $\begin{array}{l}\text { Ley } 2945 \\
\text { (2014) }\end{array}$ \\
\hline Río Negro & & & & $\begin{array}{l}\text { CP (1957): EL } \\
\text { Ley } 2227 \text { (1961): } \\
\text { EL } \\
\text { CP (1988) } \\
\text { Ley } 2444 \text { (1991) }\end{array}$ & & $\begin{array}{l}\text { Ley } 4819 \\
\text { (2012): EL }\end{array}$ \\
\hline Salta & $\begin{array}{l}\text { Ley } 31 \\
(1886) \text { : ER } \\
\text { CP (1888) } \\
\text { Ley } 164\end{array}$ & & $\begin{array}{l}\text { Ley 1695 } \\
\text { (1954): ER }\end{array}$ & $\begin{array}{l}\text { Decreto } 179 \\
\text { (1956): ER fuera } \\
\text { del HC } \\
\text { Decreto } 18 \text { (1962): }\end{array}$ & $\begin{array}{l}\text { Ley 6829 } \\
\text { (1995): ER }\end{array}$ & $\begin{array}{l}\text { Ley } 7546 \\
\text { (2008): ER } \\
\text { En dic. de } \\
2017 \text { un } \\
\end{array}$ \\
\hline
\end{tabular}




\begin{tabular}{|c|c|c|c|c|c|c|}
\hline & (1889): ER & & & $\begin{array}{l}\text { restablecimiento } \\
\text { de ER } \\
\text { Ley } 4428 \text { (1971): } \\
\text { restablecimiento } \\
\text { de Ley } 1695 \text { de } \\
1954 \text { (ER dentro } \\
\text { del HC) } \\
\text { CP }(1986) \text { : ER }\end{array}$ & & $\begin{array}{l}\text { fallo } \\
\text { judicial } \\
\text { ordenó } \\
\text { impartir } \\
\text { ER fuera } \\
\text { del HC }\end{array}$ \\
\hline San Juan & $\begin{array}{l}\text { Ley (1888) } \\
\text { CP (1927) }\end{array}$ & & $\begin{array}{l}\text { Decreto } \\
205 \text { (1944): } \\
\text { ER }\end{array}$ & $\begin{array}{l}\text { CP (1986): } \\
\text { "enseñanza no } \\
\text { confesional" }\end{array}$ & $\begin{array}{l}\text { Ley } 6755 \\
\text { (1996): ER } \\
\text { fuera HC }\end{array}$ & $\begin{array}{l}\text { Ley } 1327 \\
(2015)\end{array}$ \\
\hline San Luis & & & $\begin{array}{l}\text { Ley } 1600 \\
\text { (1944): ER } \\
\text { Ley 2507 } \\
\text { (1955): ER }\end{array}$ & $\begin{array}{l}\text { CP (1987): ER } \\
\text { fuera } \mathrm{HC}\end{array}$ & $\begin{array}{l}\text { Ley } 4947 \\
(1992)\end{array}$ & \\
\hline Santa Cruz & & & & $\begin{array}{l}\text { CP (1957) } \\
\text { Ley } 263 \text { (1961): ER } \\
\text { Ley } 1588 \text { (1988) }\end{array}$ & & $\begin{array}{l}\text { Ley } 3305 \\
(2012)\end{array}$ \\
\hline Santa Fe & $\begin{array}{l}\text { Ley (1886): } \\
\text { ER } \\
\text { CP 1900 } \\
\text { CP 1921: } \\
\text { EL (fue } \\
\text { vetada) }\end{array}$ & $\begin{array}{l}\text { Ley 2160 } \\
\text { (1932): } \\
\text { restituye CP } \\
1921 \\
\text { Ley 2369 } \\
\text { (1934): EL } \\
\text { Intervención } \\
\text { Federal de } \\
1935 \\
\text { restituye CP } \\
\text { de } 1900 \text { y } \\
\text { Ley de } 1886 \\
\text { (ER) }\end{array}$ & $\begin{array}{l}\text { Ley } 3554 \\
\text { (1949): ER }\end{array}$ & $\begin{array}{l}\text { En } 1956 \text { se } \\
\text { suprime de la Ley } \\
3554 / 49 \text { el art. } 9 \text { de } \\
\text { ER } \\
\text { CP (1962) }\end{array}$ & & \\
\hline $\begin{array}{l}\text { Santiago } \\
\text { del Estero }\end{array}$ & $\begin{array}{l}\text { CP } 1884 \\
\text { Ley } 371 \\
(1922) \\
\text { CP (1924): } \\
\text { EL }\end{array}$ & $\begin{array}{l}\text { CP (1939): } \\
\text { EL }\end{array}$ & & $\begin{array}{l}\text { Decreto } 491 \text { de } \\
\text { 1976: ER } \\
\text { CP (1986): EL } \\
\text { Ley } 5804 \text { (1989): } \\
\text { EL }\end{array}$ & $\begin{array}{l}\text { CP (1997): ER } \\
\text { CP (2002):ER }\end{array}$ & $\begin{array}{l}\text { Ley } 6876 \\
(2007)\end{array}$ \\
\hline $\begin{array}{l}\text { Tierra del } \\
\text { Fuego, } \\
\text { Antártida } \\
\text { e Islas del } \\
\text { Atlántico } \\
\text { Sur } \\
\end{array}$ & & & & $\begin{array}{l}\text { Ley } 228 \text { (1984) } \\
\text { Se provincializa } \\
\text { en } 1990 \\
\text { CP (1991): } \\
\text { “educación no } \\
\text { dogmática” }\end{array}$ & $\begin{array}{l}\text { Ley } 159 \\
(1994)\end{array}$ & $\begin{array}{l}\text { Ley } 1018 \\
\text { (2014): EL }\end{array}$ \\
\hline Tucumán & $\begin{array}{l}\text { CP } 1884 \\
\text { Ley } 1002 \\
(1908)\end{array}$ & & & $\begin{array}{l}\text { Ley } 3007 \text { (1960): } \\
\text { ER } \\
\text { Ley } 5996 \text { (1989): } \\
\text { ER } \\
\text { CP (1990): ER }\end{array}$ & $\begin{array}{l}\text { Ley } 1763 \\
\text { (2004): ER }\end{array}$ & $\begin{array}{l}\text { CP (2006): } \\
\text { ER } \\
\text { Ley } 8391 \\
\text { (2010): ER }\end{array}$ \\
\hline
\end{tabular}

Referencias: CP: Constitución Provincial; ER: enseñanza religiosa o Religión Católica según corresponda, dentro del horario de clase; EL: educación laica; HC: horario de clase; Sin referencias: neutra. Cuadro de elaboración propia en base a la normativa citada.

La Plata, septiembre de 2018. 